\title{
Mitigation on Product Launch Failure: Case Study: Brand X Nutmeg Juice Product
}

\author{
Adityo Wicaksono, Firman Tri Ajie, Tommy Hendrix \\ Pusat Inovasi \\ Lembaga Ilmu Pengetahuan Indonesia \\ Cibinong, Bogor Regency, West Java, Indonesia \\ adityo.pusinov@gmail.com
}

\begin{abstract}
Brand $\mathbf{X}$ Nutmeg Juice is one of unique product that has been produced by home industry in Bogor area. This product was started for local and very small market size. Now, this product is going to be rebranded, repackaged and launched to the market during technology business incubation stage at Center for Innovation. Mitigation steps are needed to minimize the risk of failure in the product launch. This product launch is very important, because it will determine the survival of the company. This study is using mix method, a combination between quantitative and qualitative method. Data has been analyzed using techno economic calculation, SWOT and 5 force analysis. In-depth interviews have been engaged to the business owner and incubator managers, secondary data was collected to see the external factors in order to conduct analysis and determine actions. As a result the business is feasible and there are 4 actions that need to be taken, which are : incubator should give a financial assistance for machineries and initial production cost, business owner should diversify the product (premium and regular), implement low cost leadership strategy, find a specific large buyer and involve community of buyers.
\end{abstract}

Keywords : Mitigation, Risk, Product Launch, Failure, Business.

\section{INTRODUCTION}

Indonesia has been known as the 2nd largest Nutmeg (Myristica fragrans) producer and exporter in the world after Guatemala. Its annual production reach 19,000 metric ton [1]. There are 10 provinces in Indonesia that produced nutmeg, which are : North Maluku, Maluku, Aceh, North Sulawesi, West Papua, West Java, West Sumatera, South Sulawesi, Central Sulawesi, East Nusa Tenggara.

The commodity that commonly used and has high economic value in Nutmeg are seed, fuli/arillus/mace, and myristicin/nutmeg essential oil. Mace is commonly used for spice and mace spray, while essential oil has more broader use in pharmacy, food, beverage, and fragrance industry. On the other hand, the nutmeg fruit is become a byproduct and has a very low economic value. The fruit part is $77.8 \%$ from whole nutmeg production, so the availability is abundant in Indonesia.

Bogor Regency - West Java is one of nutmeg producer center in Indonesia, it has $398.65 \mathrm{Ha}$. Wide area and produce 179.39 tons of nutmeg (BPS, 2011). Annually, Bogor has 139.56 tons of nutmeg fruit as a byproduct. The fruit has been utilized by one of home industry (company $\mathrm{x}$ ) in Bogor regency as a beverage product. This enterprise was established in 2009, with a small production capacity (1,000 bottles/ month). The products has been launched to a limited market in Bogor Regency, and promoted through several exhibition. Until 2015, company $\mathrm{x}$ has grown in a very slow pace, its production capacity reached 6,000 bottles/month, its sales reached 4,000 bottles/month. Despite of these conditions, company $\mathrm{x}$ has developed a strong network with local government institutions, farmers, suppliers and distribution channels.

In 2016, company $\mathrm{x}$ has been selected as an incubate in LIPI Technology Incubator. Through this program the development of company $\mathrm{x}$ will be accelerated and the product will be rebranded and relaunch to a broader market (Jakarta, Bogor, Depok, Tangerang and Bekasi). There is a possibility that the product relaunch will be failed and not accepted by the market. The biggest problem in product launch is lack of preparation, companies usually focused on designing and manufacturing new products that they postpone the hard work of getting ready to market them until too late in the "game" [2].

There are five other frequent problems that cause product launches fail: the company cannot support fast growth; the product falls short of claims; the new item does not have enough differentiation/ not distinctive enough to sway buyer; the product defines a new category and requires substantial consumer education but does not get it; the product is revolutionary, but there is no market for it. This is why the study must be conduct in line with the incubation program in order to mitigate these problem.

\section{LITERATURE REVIEW}

Risk mitigation is one of important part in risk management. Risk management consist of risk assessment and risk control. Risk assessment involves risk identification, risk analysis, and risk prioritization. Meanwhile, risk control involves risk planning, risk mitigation, and risk monitoring [3]. Risk management is a process that is underpinned by a set of principles, and it needs to be supported by a structure that is appropriate to the organisation and its external environment. A successful risk management initiative should be proportionate to the level of risk in the organisation (as related to the size, nature and complexity of the organisation), aligned with other corporate activities, comprehensive in its scope, embedded 
into routine activities and dynamic by being responsive to changing circumstances [4]

Risk Mitigation involves two steps, which are : identifying actions to reduce the probability/impact of an adverse failure or disaster, and creation of a contingency plan to deal with the risk before it occur. In ideal condition risk mitigation should : characterize the root causes of identified risks and quantified in earlier phases of the risk management process, evaluate risk interactions and common causes, identify alternatif mitigation strategies, method or tools for each major risk, asses and prioritize mitigation alternatives, and lastly select and commit the resources required for specific risk mitigation alternatives [5].

\section{METHODOLOGY}

This study is using mix method [6], a combination between quantitative and qualitative method. Quantitative data's has been analyzed using techno economic calculation to understand the feasibility and business value. While qualitative data's has been analyzed using SWOT and 5 force analysis to determine actions (see fig.1). In-depth interviews have been engaged to the business owner and incubator managers, secondary data's were collected to see the external factors and to conduct business analysis. By using mix method this study can provide a comprehensive strategy in mitigating product launch failures.

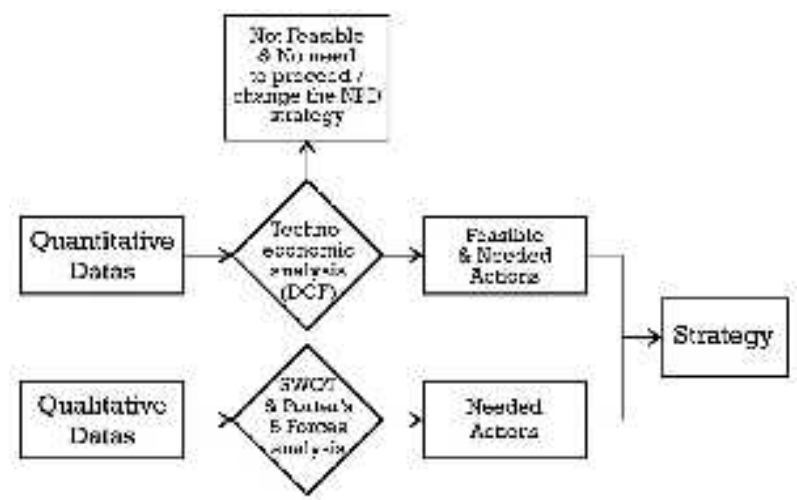

Fig. 1. Research method

\section{INCUBATION PROGRAM FOR NUTMEG JUICE PRODUCTION BUSINESS AS A FAILURE MITIGATION}

LIPI Incubator is a government institution that provide Incubation program for New Technology Based Firm (NTBF) and premature businesses to be able to increase their capacities and capabilities by applying technology and proper business plan. This program also mitigate NTBFs to fail in the development process until they reached product launch (New Product Development / NPD) and pass "the valley of death" [7] (see fig. 2). Incubator will give funding to the firms although there is a high risk that the development process might fail and no financial benefit will return to the incubator. But the high number of failure will cause the incubator having a bad performance in its annual reports, so incubator manager need to minimize these number by doing some analysis and assessments before jump into actions.

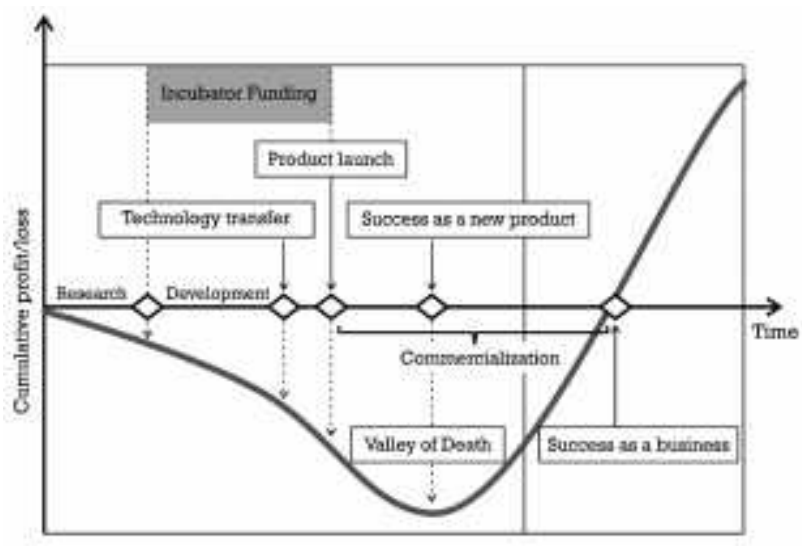

Fig. 2. Valley of death. (Modified from Osawa \& Miyazaki, 2006)

Incubation process includes 4 stages, which are: registration, selection, pre/incubation, graduation [8] (see fig. 3 ). The process of incubation will take 2 to 3 years depends on the complexity of development process and it can be done in wall or out wall. The first year will be very crucial to NTBF, which is the development of new or enhanced product. Product development stage will take time about 4 up to 10 months, and after that the product will be launch to the targeted market.

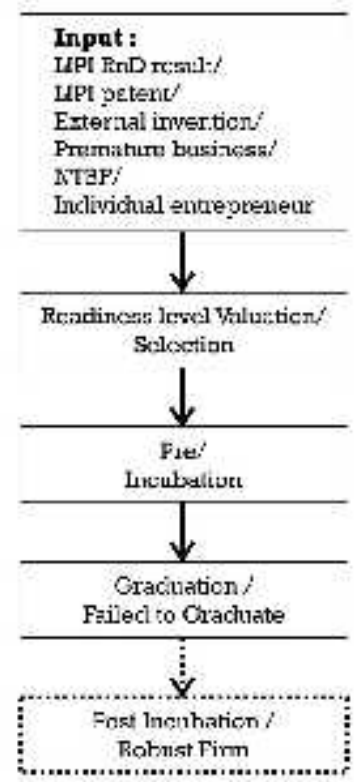

Fig. 3. Incubation process in LIPI. (Modified from Selection Guide for LIPI Technology Incubation, 2015)

For the case of nutmeg juice production, the product development process has been decided to be done in 6 month, started in May 2016. Incubator gave several facilities to company $\mathrm{x}$, such as: funding, training, mentoring and promotion. Several machineries have been applied, include: ozonize, ionizer, screw press, sterilization equipment, and bottle cap press. With these, the production process is more hygiene and efficient than before (see fig. 4). 


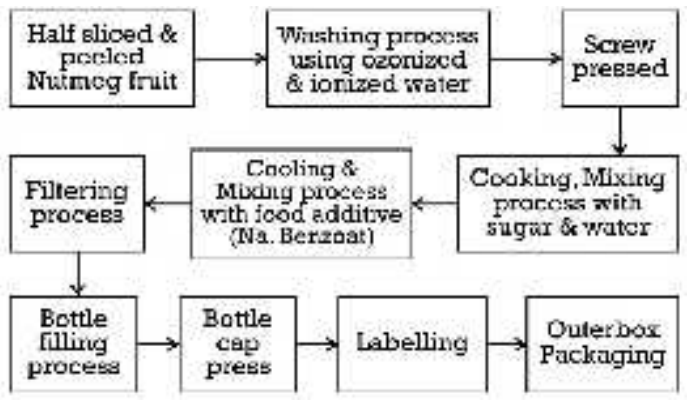

Fig. 4. Brand X Nutmeg juice production process.

\section{TECHNO ECONOMIC CALCULATION}

The first step on analyzing the techno economic of brand $\mathrm{x}$ nutmeg juice product is to determine production capacity and to identify the $5 \mathrm{M}$ factors (man, material, machine, method, and money). Through incubation program the production capacity were planned to be increase up to 20,400 bottle/month and 244,800 bottle/year. Furthermore, the $5 \mathrm{M}$ factors were identified from interviews with business owner.

In producing 20,400 bottle/month the company need 5 man power and 5 machines. For the materials include: $4,080 \mathrm{~kg}$ of nutmeg fruits, $979 \mathrm{~kg}$ sugar and $40 \mathrm{~kg} \mathrm{Na}$. Benzoate. Annually, the total cost of material is IDR. 283,968,000, it's about $31 \%$ of total production cost (IDR. 911,751,000). The bigger component of production cost is packaging, it reached IDR $468,792,000$ (50\% of total cost). With estimated selling price at IDR 6,000, the annual net profit will be IDR. 373,802,000 ( $100 \%$ capacity after 3 years)

The second step for techno economic calculation is to determine the feasibility of the business on this new product, using Discounted Cash Flow Method (DCF Method) [9]. In calculating the DCF, several things need to be done to be able to draw conclusions, which are: a cash flow projection, calculation of Net Present Value (NPV), Internal Rate of Return (IRR), Benefit Cost Ratio (BCR) and Payback period.

NPV was used to measure the excess or short fall of cash flow in present value terms. The formula can be written as in (1):

$$
\begin{aligned}
& \text { NPV }=\mathbf{Z}(\mathbf{B}-\mathbf{C t}) /(\mathbf{1}+\mathbf{i}) \\
& \text { Whereas: } \\
& \text { B= Benefit/Revenue } \\
& \mathrm{C}=\text { Cost } \\
& \mathrm{i}=\text { interest } \\
& \mathrm{t}=\text { Time frame }
\end{aligned}
$$

The NPV for nutmeg juice business is IDR 953,640,000. This means that the nutmeg juice business is able to add a value of IDR 953,640,000 to the firm, therefore the investment would be viable

IRR has been used to evaluate the desirability of investments or business, or as an indicator of the efficiency, quality, or yield of an investment. The formula of IRR is as written in (2)

$\operatorname{IRR}=\mathbf{Z}\left\{(\mathrm{B}-\mathrm{Ct}) /(\mathbf{1}+\mathbf{i})^{*}\right\} \mathbf{0}$
The IRR calculation result is $46.8 \%$, higher than the established minimum acceptable rate of return or cost of capital (6\% hurdle rate). Therefore, an investment for producing nutmeg juice simultaneously is highly acceptable.

$\mathrm{BCR}$ reflects the ratio of how much benefit / profit that can be generated from an investment compared to the cost. The $\mathrm{BCR}$ formula is as written in (3)

$$
\mathbf{B C R}=\mathbf{Z}\left\{\mathrm{B} /(\mathbf{1}+\mathbf{i})^{6}\right\} / \mathrm{Z}\left\{\mathrm{C}, /(\mathbf{1}+\mathbf{i})^{6}\right\}
$$

The BCR for production of nutmeg juice is 1.61. This indicates that the investment will be profitable because the BCR value is higher than 1.0.

Payback Period estimation for the investments on nutmeg juice business calculated from the cumulated gross profit and depreciation. For investment IDR 392,740,000 the payback period is 20 months.

The techno economic calculation showed that, this business is feasible to proceed and also has high potency of becoming a successful business, but there are some part in the production cost and investment that too big to afford by the business owner. If its fail and she cannot cover that part, then the business will not be able to survive after the product launch. This should be mitigate by the incubator.

\section{SWOT ANALYSIS}

\begin{tabular}{|c|c|c|c|}
\hline Strength (S) & Score & Scale & Total \\
\hline Unique taste & 7.5 & 0.3 & 2.25 \\
\hline $\begin{array}{l}\text { Cheaper than } \\
\text { competitor / similar } \\
\text { product }\end{array}$ & 8 & 0.25 & 2 \\
\hline Indigenous to Bogor & 8 & 0.2 & 1.6 \\
\hline $\begin{array}{l}\text { Already has permit \& } \\
\text { halal certification }\end{array}$ & 7.5 & 0.15 & 1.125 \\
\hline $\begin{array}{l}\text { Atractive packaging } \\
\text { design }\end{array}$ & 6.5 & 0.1 & 0.65 \\
\hline \multicolumn{3}{|l|}{ Total S } & 7.625 \\
\hline \multicolumn{4}{|l|}{ Weakness (W) } \\
\hline $\begin{array}{l}\text { Unfamiliar taste to the } \\
\text { targeted consumer }\end{array}$ & 8 & 0.4 & 3.2 \\
\hline $\begin{array}{l}\text { Unstandarized } \\
\text { production }\end{array}$ & 7 & 0.3 & 2.1 \\
\hline $\begin{array}{l}\text { Lack of capital to } \\
\text { purchase bottle and } \\
\text { label, lead to the higher } \\
\text { cost }\end{array}$ & 7 & 0.3 & 2.1 \\
\hline \multicolumn{3}{|l|}{ Total W } & 7.4 \\
\hline \multicolumn{3}{|c|}{$\mathbf{S}-\mathbf{W}$} & 0.225 \\
\hline
\end{tabular}

Pearce and Robinson SWOT analysis approach [10] has been used to understand the internal and external factors of the product and to determine action. Marketing intelligence [11] was conducted to gather internal and external data for SWOT analysis. The result of SWOT analysis is showed in table1.

Table 1. SWOT Analysis Matrix 
(Table I, cont.)

\begin{tabular}{|c|c|c|c|}
\hline \multicolumn{4}{|l|}{ Opportunities (0) } \\
\hline $\begin{array}{l}\text { Wide market for } \\
\text { Jabodetabek }\end{array}$ & 7 & 0.5 & 3.5 \\
\hline $\begin{array}{l}\text { Low number of } \\
\text { competitor }\end{array}$ & 8 & 0.5 & 4 \\
\hline \multicolumn{3}{|l|}{ Total Opportunities } & 7.5 \\
\hline \multicolumn{4}{|l|}{ Threats (T) } \\
\hline $\begin{array}{l}\text { There is already a big } \\
\text { player as a competitor }\end{array}$ & 8 & 0.6 & 4.8 \\
\hline $\begin{array}{l}\text { Strict product } \\
\text { requirement to enter } \\
\text { modern market }\end{array}$ & 7 & 0.4 & 2.8 \\
\hline \multicolumn{3}{|l|}{ Total Threats } & 7.6 \\
\hline \multicolumn{3}{|c|}{$\mathbf{O}-\mathbf{T}$} & -0.1 \\
\hline
\end{tabular}

The result of SWOT analysis matrix showed that StrengthWeakness is positive (+), and Opportunity-Threat is negative (). This placed in SWOT quadrant as shown in fig.5.

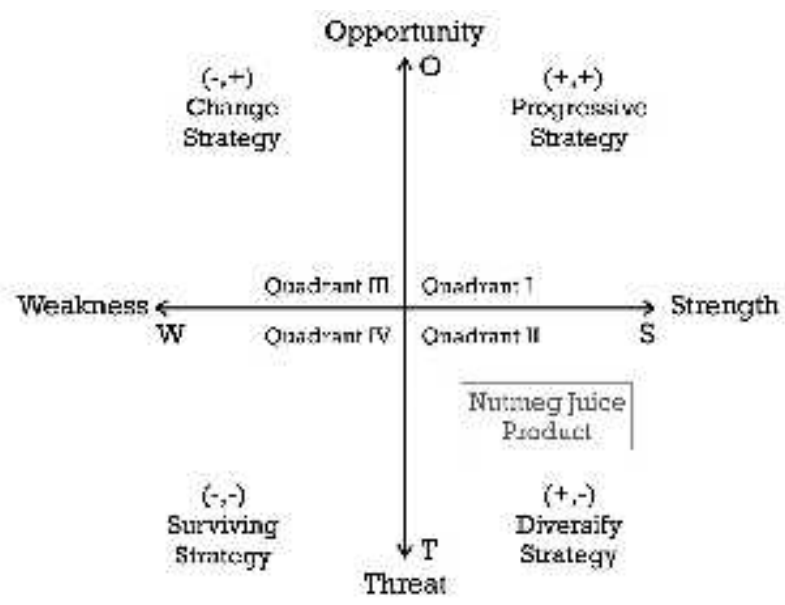

Fig. 5. Brand X nutmeg juice product SWOT analysis quadrant

Referring to Pearce and Robinson, there are 4 quadrant of SWOT analysis related to the internal and external factors, resulting strategy that suit with the condition. In this case, nutmeg juice product is on $2^{\text {nd }}$ quadrant, and the proper strategy would be to diversifying strategy.

\section{PORTER'S 5 FORCE ANALYSIS}

Porter's 5 Force analysis [12] has been used to comprehend the barrier to entry for new nutmeg juice product. Informations were collected from many source, involving suppliers, local government official, business owner, incubator manager, and secondary data to drawn five factors that determine the nature of competition and barriers of entry. The 5 factors are : bargaining power of suppliers, threat of substitute products, threat of new entrants to a market, bargaining power of customers (buyers), degree of competitive rivalry (see fig. 6).

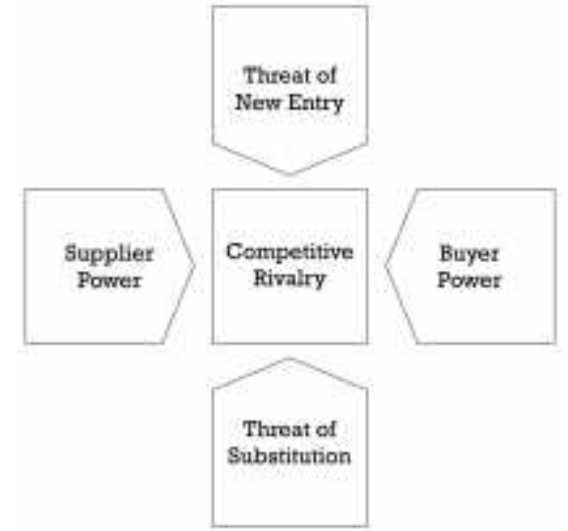

Fig. 6. Porter's five forces model

\begin{tabular}{|c|c|c|}
\hline Factors & $+1=$ & Nature \\
\hline $\begin{array}{l}\text { Supplier } \\
\text { Power }\end{array}$ & + & $\begin{array}{l}\text { (+) Avallability of material is abundance. } \\
\text { (+) Material price is low and not Auctuated. } \\
\text { (+) Plenty of auppliers. } \\
\text { (-) High prico for minimum order for label } \\
\text { print. } \\
\text { ( ) High and fluctuated price for augar. }\end{array}$ \\
\hline $\begin{array}{l}\text { Threat of } \\
\text { Substitution }\end{array}$ & - & $\begin{array}{l}\text { (-) Many beverages can subatitute the } \\
\text { product } \\
\text { (-) Many big beverages business already in } \\
\text { the market } \\
\text { (-) Mimost similar to tea with flavor which } \\
\text { atready popular. } \\
(+) \text { The trend is heading to healthy drink } \\
\text { (+) Popular local brand for FriB product can } \\
\text { easily }\end{array}$ \\
\hline $\begin{array}{l}\text { Threat of } \\
\text { New Entry }\end{array}$ & + & $\begin{array}{l}\text { (+) Difficult to find the right/preferred flavor. } \\
(+) \text { Investment cost in machineries cannot be } \\
\text { afford by many start up or amall medium } \\
\text { enterprises. } \\
\text { (+) Production cost of proper packaging is } \\
\text { high for small size procurement, this can } \\
\text { make the selling price not competitive. } \\
(+) \text { Lack accoss to modern maricet. } \\
(-) \text { This product can be produced manually } \\
\text { with umall size capacity and small } \\
\text { investment. } \\
(-) \text { Easy to find supplier and material }\end{array}$ \\
\hline $\begin{array}{l}\text { Buyer } \\
\text { Power }\end{array}$ & - & $\begin{array}{l}\text { (-) Consumer has many option for } \\
\text { beverages product. } \\
\text { (-) Limited number of eustomer in local } \\
\text { marioet (non modern market). } \\
\text { (-) Customer can easily switch to other } \\
\text { product. } \\
\text { (+) New product with good } \\
\text { recomimendation from customers (words } \\
\text { of mouth) can attract many other } \\
\text { cuatomer through social media. }\end{array}$ \\
\hline $\begin{array}{c}\text { Competitive } \\
\text { Rivalry }\end{array}$ & + & $\begin{array}{l}\text { (+) Small number of competitor ( } 8 \text { similar } \\
\text { nutmeg juice producer) in Bogor. } \\
\text { (+) Big and growing market rize for } \\
\text { Jabodetabeik especially modern } \\
\text { market. } \\
\text { (4) Brand } x \text { mutmeg juice has big } \\
\text { differentiation regarding its taste and } \\
\text { color. } \\
\text { (4) New potential rarket for prernium } \\
\text { nutmeg juice product which are : hotel, } \\
\text { and foreign tourists in jabodetabek. } \\
\text { (-) Small maarket nizo for Bogor gift shop. }\end{array}$ \\
\hline
\end{tabular}

Fig. 7. Porter's five forces analysis for brand X nutmeg juice product. 
The 5 factors analysis for nutmeg juice product (see fig. 7) showed that supplier power is low (+), it means business owner can have advantages, such as: low price of materials, less fluctuative price, easy to switch supplier. This condition does not need special strategies. On the contrary, threat of substitution is high (-), it means that nutmeg juice product can easily substitute with beverages product in the market and difficult to enter the market, because there are already many option of beverages with various price. This condition will require a proper strategy to get the nutmeg juice product to enter the market.

Furthermore, threat of new entry is high $(+)$ this is supportive for the business to limit the competitor to enter the market and no need special strategies. While, buyer power is high (-), this will require a proper strategy. Moreover, the competitive rivalry is low and the market size is growing (+) this condition has a positive impact and supportive for the business and no need for a special strategy.

So, there are 2 factors that require a proper strategy, which are: higher threat of substitution and higher buyer power. Referring to Porter's competitive strategies there are 3 types of approach/strategy that company can choose to adapt to the situation, which are : a low-cost leadership strategy, differentiation strategy, and a focus or niche strategy [13]. There is 2 proper strategy for current nutmeg juice business nature, which is a low-cost leadership strategy and a focus or niche strategy (see fig.8)

\begin{tabular}{|c|c|c|c|}
\hline \multirow{2}{*}{\multicolumn{2}{|c|}{$\begin{array}{l}\text { Porter's } \\
\text { Approach }\end{array}$}} & \multicolumn{2}{|c|}{ Strategic Advantage } \\
\hline & & Exclusw:ty percerved & Competence in/ \\
\hline \multirow{2}{*}{ 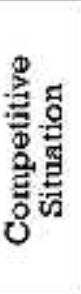 } & 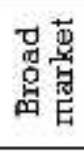 & $\begin{array}{l}\text { Differentiation } \\
\text { strategy }\end{array}$ & $\begin{array}{l}\text { lovi cost } \\
\text { leadership strategy } \\
\text { Coumsring higher } \\
\text { throst of substiution }\end{array}$ \\
\hline & 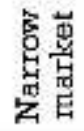 & \multicolumn{2}{|c|}{$\begin{array}{c}\text { Focus or riche strategy } \\
\bullet \\
\text { ceuntering hugher } \\
\text { bi. yerr poraser }\end{array}$} \\
\hline
\end{tabular}

Fig. 8. Porter's competitive strategy matrix.

Low cost leadership strategy is suitable for company which aim for broader market, higher threat of substitution and have the competence to maintain low production cost. This means that company should suppress most components of production at a low cost to be able to set the new product at a low selling price when entering the market (at product launch stage).

Focus or niche strategy will be fit for company to enter a narrow market with low level of competition/ rivalry, where buyer needs are distinctively different from the rest of the market. This will require strong networks and insight to earn that specific buyer or niche. Involving community of customers is one of unique and new strategy that can be applied in NTBF or start up. This strategy was applied by Thread less, a young fashion company in Chicago, and made this company successfully launch their new products [14]. If in this fashion company involve hobbyist, and professional graphic designers as its community of customers, so for nutmeg juice business can involve indigenous food and beverage store owners in Bogor, Hotel and Restaurant owners in Bogor.

\section{VIII.BRAND X NUTMEG JUICE PRODUCT LAUNCH FAILURE MITIGATION STRATEGY}

A comprehensive mitigation strategy is develop from 3 analysis, which generate required actions that should be taken by the business owner. The process is as drawn in fig. 9 .

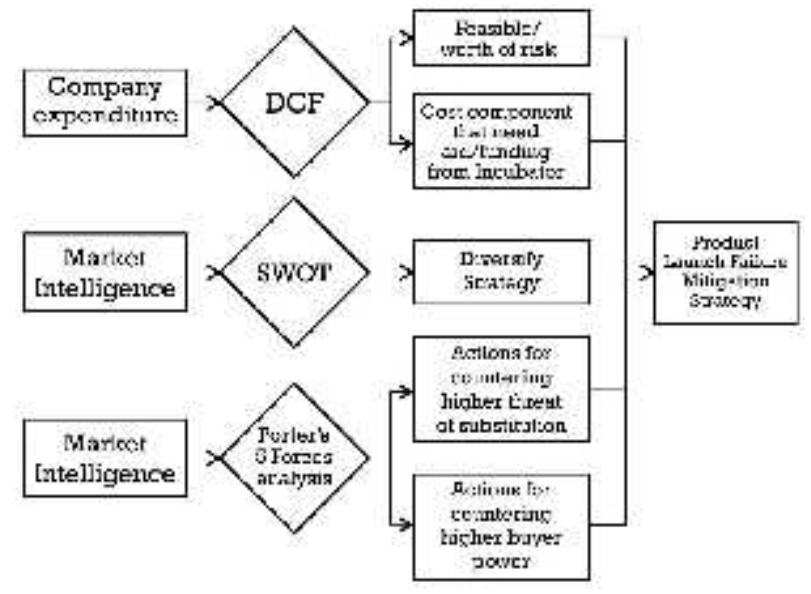

Fig. 9. Process on developing product launch failure mitigation strategy.

There are 4 required actions that will help to mitigate failures in brand $\mathrm{x}$ nutmeg juice product launch phase, after knowing that the business is feasible (worth the risk), which are : incubator give a financial assistance on cost component that cannot afford by business owner, diversify strategy (diversify product - premium nutmeg juice, aim different target market hotel \& restaurant, aim for modern market), use a low pricing strategy in early phase, find a specific large buyer and involve community of buyers in NPD process (see fig. 10).

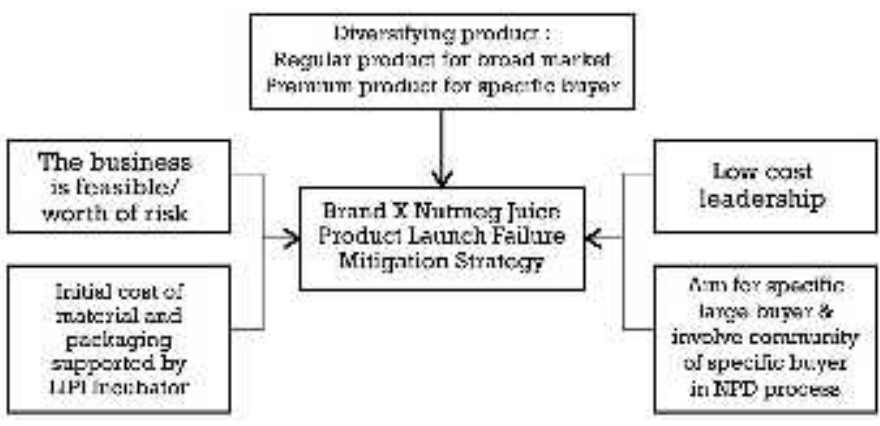

Fig. 10. Nutmeg juice product launch filure mitigation strategy.

This strategy will be implemented in the brand $\mathrm{x}$ nutmeg juice incubation / new product development process in 2016, while the new product will be launch in the end of 2016. 


\section{CONCLUSION}

After acknowledging that the business is feasible by DCF calculation, business owner and incubator manager should understand that there are components of initial production cost need to be supported by LIPI incubator. Diversifying product is needed to tackle the high threat of competition with big player and the difficulty to enter modern market. The regular product will be develop to enter broad and modern market, while premium product should be developed to aim specific buyer. Lowering product selling price for product launch stage is a must, to sway buyers. For this, business owner need to suppress the production cost.

In addition, the company need to find a specific large buyer or niche in the market. After find a specific buyer, company should acquire its specific needs, that is why community of specific buyer should be involved in the NPD process.

This study was conducted only for preliminary process of brand $\mathrm{x}$ nutmeg juice product launch, therefore further research is needed to measure the success of the mitigation strategy.

\section{ACKNOWLEDGMENT}

Firstly, author would like to thank to business owner of brand $x$ nutmeg juice product, who gave such a great opportunity in conducting study on her business. Secondly, author also thank to LIPI Incubator Manager, and Director of Center for Innovation LIPI, who have provided informations and discussions in completing this study

\section{REFERENCES}

[1] Anonymous, http://www.mapsofworld.com, 2016.

[2] Schneider, J. and Hall, J., "Why most product launches fail," Harvard Business Review, April 2011.

[3] Boehm, B., "Software risk management," IEEE Computer Society Press, Washington, DC., 1989.

[4] The Association of Insurance and Risk Managers, A structured approach to enterprise risk management (ERM) and the requirements of ISO $31000,2010$.

[5] Committee for Oversight and Assessment of US. Department of Energy Project Management, "The owner's role in project risk management," 2005.

[6] Creswell, John W., "Research design;qualitative, quantitative, amd mix methods approaches," 2003.

[7] Osawa,Y. and Miyazaki, K., "An empirical analysis of the valley of death: Large-scale R\&D project performance in a japanese diversified company," Asian Journal of Technology Innovation, p.93-116, February 2011.

[8] Center for Innovation, "Selection guide for LIPI technology incubation," 2015.

[9] R.J.K., McIntosh, "Discounted cash flow: their current use," val. land econ, 1993.

[10] Pearce, John A. and Robinson Jr., Richard B., "Strategic management", 1998.

[11] Tan, T.T.W., and Ahmad, Z.U., "Managing marketing intelligence: an asian marketing research perspective", Marketing Intelligence \& Planning, 17(6), pp. 298-306, 1999.

[12] Porter, M., "Competitive advantage", Simon \& Schuster, New York, 1985.

[13] Porter, M., "Competitive strategy; techniques for analyzing industries and competitors", New York, 1980.

[14] Ogawa,S. and Piller, Frank T., "Reducing the risks of new product development", MIT sloan management review, 2008. 